Meta

Journal des traducteurs

Translators' Journal

\title{
Morphovariation and Synonymy of Acronyms
}

\section{Félix Rodríguez González}

Volume 38, numéro 2, juin 1993

URI : https://id.erudit.org/iderudit/002941ar

DOI : https://doi.org/10.7202/002941ar

Aller au sommaire du numéro

Éditeur(s)

Les Presses de l'Université de Montréal

ISSN

0026-0452 (imprimé)

1492-1421 (numérique)

Découvrir la revue

Citer cet article

Rodríguez González, F. (1993). Morphovariation and Synonymy of Acronyms. Meta, 38(2), 275-292. https://doi.org/10.7202/002941ar

\section{Résumé de l'article}

Dans cet article, nous examinons l'usage fait des diverses formes d'acronymes pour représenter la même expression ou la même dénomination. Ce phénomène, typique dans de nombreuses langues, sera désigné ici par le " terme acronymes doubles ". Ces derniers sont liés par une relation de synonymie, ou plutôt d'équivalence lexicale, nombre d'entre eux constituant en effet de pures formes morphovariées, avec de légères différences dans leurs représentations syntagmatiques sous-jacentes. d'utilisation que vous pouvez consulter en ligne.

https://apropos.erudit.org/fr/usagers/politique-dutilisation/ 


\title{
MORPHOVARIATION AND SYNONYMY OF ACRONYMS
}

FÉLIX RODRÍGUEZ GONZÁLEZ

Université of Alicante. Alicante, Spain

\begin{abstract}
Résumé
Dans cet article, nous examinons l'usage fait des diverses formes d'acronymes pour représenter la même expression ou la même dénomination. Ce phénomène, typique dans de nombreuses langues, sera désigné ici par le «terme acronymes doubles». Ces derniers sont liés par une relation de synonymie, ou plutôt d'équivalence lexicale, nombre d'entre eux constituant en effet de pures formes morphovariées, avec de légères différences dans leurs représentations syntagmatiques sous-jacentes.
\end{abstract}

In the present article I examine the use of varying acronym forms to represent the same phrase or denomination, a phenomenon which is noticeable in the most diverse languages. Henceforward this phenomenon will be referred to as double acronyms since it is normally two phrases which are represented. The relation between these acronyms is one of synonymy, or rather of lexical equivalence for many of them are actually mere morphovaried forms, with slight differences in their underlying syuntagmatic representations.

If we look into the sources of double acronyms, the following patterns can be distinguished:

1) Double phonetic-graphemic representation of the underlying phrase: ESC/ECOSOCO (Economic and Social Council).

2) Ellipsis: EEC/EC (European Economic Community/European Community).

3) Double underlying phrase: RIF (reduction in force)/RIP (reduction in personnel).

4) Double code (or translation): North Atlantic Treaty Organization (NATO)/Organización del Tratado del Atlántico Norte (OTAN).

If these are the main reasons which account for the occurrence of such forms in the language, there are various linguistic and pragmatic or sociolinguistic conditions involved in selecting a particular variant. To determine them will be the aim of this paper. Although the data collected come basically from Spanish, an account of the phenomenon as it appears in other languages is also given.

\section{DOUBLE PHONETIC-GRAPHEMIC REPRESENTATION}

Perhaps the most simple and visible procedure by which varying acronyms forms are originated, especially in writing, is linked to the very process of formation of acronyms. It can be noted that the coining of an acronym form does not follow fixed rules with regard to the choice of the initials. Every element of the base syntagm can be symbolized by way of a letter, syllable or segment, or it may not even be represented in any feasible way. Confronted with the selection of such diverse methods, users at times coin two or more forms almost simultaneously. Thus for example, a European Economic Community institution like the Economic and Social Council is abbreviated in English according to its first initials (ESC), but also according to syllabic groups of 2 or 3 initials (ECSOCO, ECOSOCO). The African Development Bank is known as AfDB and ADB. 
Likewise in French the comité des représentants permanents has given rise to COREPER and CRP (cf. Conseil 1983).

Similar doublets are attested in Spanish, as is shown by BIC/BRIC (Brigada de investigación criminal), COB / COBOL (Central Obrera Boliviana), DEAC/DAC (Departamento de Actividades Culturales) ${ }^{1}$ PYME/PME (Pequeña y Mediana Empresa).

These fluctuations are to be regretted, especially when they appear within the same linguistic or speech community, since they may cause confusion to the receiver — reader or listener - although continuous use may end up favouring only one form.

When the acronym has been recently coined or its use has not been consolidated, vacillations may occur over a period of time within a given publication. Shortly after the creation in Nicaragua of the political group Alianza Revolucionaria Democrática, led by the mythical Edén Pastora, the initials ARD turned up in some Spanish journals together with ARDE, which was the form that was eventually to prevail. It seems then as if the journalist, guided by what he might consider to be the natural form, would ingenuously believe that such was the true acronym, or that he used it as an ad hoc symbol to avoid the recurrence of extensive denominations within the text. But, as we can see, our assumptions do not always coincide with reality and in time the "correct" form established is the one used by the social or political group that gave it birth.

It goes without saying that vacillations are more likely to occur, and more difficult to root out, when we look at their use in different publications, especially if the acronym is not well known or much used. A good case in point is the name of the Spanish linguistic periodical Estudios de Lingüistica de la Universidad de Alicante for which the initials ELUA were coined in an attempt to give them an "acronymic" shape, but which is cited in the Modern Language Association (MLA) bibliography repertoire, for example, using the abbreviation EdLing.

It is quite clear in this case that the documentalist, not being familiar with the acronym, has designed an abbreviation of his own making. This process seems to be understandable but when such conditions are not met and the potential readership and the number of users is larger, as happens in the political field, the multiplicity of forms is to be avoided. Thus one cannot but reject the unusual forms J.J.E.M. ${ }^{2}$ (Junta de Jefes del Estado Mayor) and SDTV ${ }^{3}$ (Solidaridad de Trabajadores Vascos) which may owe their existence to a careless segmentation of the phrases, for at the time in which they were documented JUJEM and STV were the established variants.

Neither does it seem to be very convenient to make use of such variations in the same text as a stylistic co-referential device. This is what happens in a news report of La Vanguardia Española (8/4/1981: 39) in which PYMES recurs as the plural form of PYME, the general form, whereas in the headline we find the occasional variant PME, which is the form used also in French (PME, petite et moyenne enterprise). We can assume that this variation is intentional since the two schemas recur in acronymic lexemes derived from extensions of such initials: if on the one hand we find CEPYME (Confederación de la Pequeña y Mediana Empresa) or PYMECO (Pequeña y Mediana Empresa Comercial), on the other the Banco de la Pequeña y Mediana Empresa bears the initials BPME as its logotype, and the Asociación de la Pequeña y Mediana Empresa del Metal de Navarra is abbreviated as APMEN.

The situation is further complicated if one considers that in Catalan the form used is, for obvious reasons, PIME (Petita i Mitjiana Empresa). This fact would explain the occurrence of acronyms like PIMEM (Pequeña y Mediana Empresa de Mallorca) and PIMEC (Pequeña y Mediana Empresa de Cataluña) in Peninsular Spanish texts.

One might attribute this to a wish to adjust acronyms to Spanish orthographic rules, but such agreement is not a principle normally followed when they are coined; rather, 
acronyms are sometimes inclined to show a "hypercharacterizing" spelling4. For this reason we do not hesitate to write FORPPA (Fondo de Ordenación y Regulación de Productos y Precios Agrarios), with a geminated P; occasionally the form found is FORPA ${ }^{5}$, with a single $\mathrm{P}$, although this could also be attributed to an error in interpretation ${ }^{6}$.

If one excludes orthographic variations of this kind, and others involving the capital or small character of the graphemes, he will notice that the choice of the established variant is made in accordance with its sonority (JUJEM, PYME, ARDE) and/or brevity (BIC, $\mathrm{COB})$. In most cases variation agrees with a two-way pattern of formation of acronyms, "initialistic" (PME, ARD) and "acronymic" or "syllabic" (PYME, ARDE, BIC, JUJEM)", the latter providing the lexeme with greater euphony.

Now, the shape of the "acronymic" lexeme can also be established on semantic grounds, for acronyms can easily take an "acrostic" form (Rodríguez González 1983: 211; 1984a) which may produce striking connotative effects. Thus the aforementioned initials ARDE, apart from their "acronym" (stricto sensu) condition, helps to connote the subversion of the order instituted in Nicaragua: its association with the act of arder ("burning") is in fact very well fitted to refer to a guerrilla faction opposed to the Sandinista central government.

Occasionally the two variants are persistently used and this may occur if the form which is considered "anomalous" (i.e. not original) is used deliberately with expressive purposes. Such is the case of Spanish FELIPE or Felipe, which is the term the opposition political group FLP (Frente de Liberación Nacional) has been popularly known by since the 50's, or PAPO ("double chin") and Pepe, a hypocoristic form of José (Joseph) frequently used in the press of the 70's to refer to the centrist P.P. (Partido Popular) party.

A different pattern of variation is found in the use of abbreviations and acronyms proper to represent plural names or denominations - FF.AA., FAS (Fuerzas Armadas), JJ.SS, JS (Juventudes Socialistas), NN.UU., N.U. (Naciones Unidas) - or the plural of nouns - PCs, PP.CC. (partidos comunistas) - . Some doublets are formed from denominations where we find other processes such as ellipsis or extensions, which will be analysed later; e.g. EE.UU. (Estados Unidos). EUA (Estados Unidos de América); N.U., NN.UU. (Naciones Unidas), ONU (Organización de las Naciones Unidas); CC.AA. (Comandos Autónomos), CAA (Comandos Autónomos Anticapitalistas).

A similar pattern is that which opposes an acronym to an abbreviation formed by "semiacronymized" phrases like $U$. States (US, United States), N. York (NY, New York), D-Mark (DM, Deutsch Mark), PC español (PCE, Partido Comunista de España), or others of a similar sort, such as $B O$ de $E$ (BOE, Boletín Oficial del Estado), UG de $T$ (UGT, Unión General de Trabajadores), PS de $G$ (PSG, Partido Socialista de Galicia), EM de $T$ (EMT, Empresa Municipal de Transportes), AC de P (ACP, Asociación Católica de Propagandistas), $S$ de $N$ (Sociedad de Naciones), which might be termed "split acronyms". I say that it is a similar pattern because these special acronyms are usually pronounced in their full forms (that is, as "abbreviations") and there are very few, like English US of $A$ /ju:-es- $\partial \mathrm{v}-\mathrm{ei} /$ or $C$ of $E / \mathrm{si}-\partial \mathrm{v}-\mathrm{i}: /$ (Church of England), which achieve a certain degree of lexicalization and have their initials pronounced (that is, as "initialism" or "literation"). They are also similar inasmuch as the latter acronyms and some of the former are sometimes used alternatively for stylistic purposes, a practice which is much rarer among acronyms proper. This similarity extends to the process of formation, since both kinds, in so much as they are technically "abbreviations", constitute on the whole the first stage in the process of acronymy: thus, for example, FF.AA. and $B O$ del $E$. took some time to be shortened to the current acronyms FAS / fas / and BOE / boe /; and in English US was preceeded by $U$. States, which was very common at the beginning of the Republic (Hockett 1958), and US of $A$ which was frequently used in the XIX century (De Sola 1987). 
Finally, from a diachronic perspective one could mention the changes made in some acronym denominations for various reasons. This is the case of the Intercontinental Ballistic Missile or IBM, as it was termed in the military jargon of the 50 's, now abbreviated into ICBM, which is probably due to the extensive use of IBM, International Business Machines, meaning computers (cf. Rodríguez González 1983: 210, n. 3).

\section{ELLIPSIS}

A second way by which one arrives at a double acronym is ellipsis. When a phrase reaches a high frequency of usage the natural tendency towards economy of expression may lead to the omission of some of its elements if they are considered superfluous or easily understood. The same occurs to their acronyms. In English European Economic Community/European Community and in Spanish Comunidad Económica Europeal Comunidad Europea are alternative forms, and the same applies to their corresponding initials, EEC/EC and CEE/CE.

The Spanish examples are a good illustration of the elliptical process because of the recent variation found in them. Until recently, CEE was the only abbreviated form, but after the recent integration of Spain into the European institution and the need to make continuous references to news related to it, the acronym was further reduced. It is not by chance that the shortening of CEE to CE made an early appeareance and is consistently used today in El País, a daily where European economic and political matters receive regular and extensive coverage. Most of the newspapers, however, stick to the original and standard form, although in some other dailies like Diario 16 the two variants are still frequently found.

In the English press the alternating variants are rarely registered within a single newspaper and often the different media favour only one of them. Thus, whereas the dailies The Daily Telegraph, The Times and The Guardian systematically use EEC, The Financial Times and The Independent turn to $\mathrm{EC}^{8}$.

A rather unusual case can be found in the article "Canada to raise issue of EC's oils levy" of the Malasian daily New Straits Times $(26 / 5 / 1987)$ where twice the journalist has resorted to the alternation of EC and EEC for clearly stylistic reasons:

Dr. Slim spoke on the EEC's proposed levy on vegetable oils and fat $[\ldots]$ the EC Council of Ministers...

While there have been positive signs of price support restraint in the EEC, the cairns group is concerned over the EC's proposal to introduce a consumer tax $[\ldots]$.

Finally, it should be stressed that the reduction by way of ellipsis both in English and in Spanish in such examples is characteristic of written language, and this process is no doubt facilitated by the fact that the ellipted initial is part of a cluster formed by two identical vowels. It rarely has an effect in spoken language, in particular in the news bulletins where the European institution is more frequently mentioned, for if the two E's were not distinctly heard in the flow of the speech the acronym would be difficult to recognize.

However, more important than these linguistic conditioning factors are others of an extralinguistic nature. The ellipsis has taken place in an era characterized by the political and social development of the European community which has gone beyond the original economic project. It is for this reason that the phenomenon also occurs in German (EWG, Europäisches Wirtschaftsgemeinschaft / EG, Europäische Gemeinschaft), even though the special graphemic and phonological conditions of English and Spanish do not exist. In EWG there is no vowel cluster and hence the generalization of the variant EG, even in the spoken language. 
Another typical, older and much better known example of ellipsis is the pair United States of America (USA)/ United States (US). The conditions of usage of these two variants in English are very different for they show a clear complementary distribution with regard to at least two factors: register (formal or informal) and syntactic function. Newspaper stylebooks have traditionally advocated the use of the complete form USA, which is the official name of the country (hence the well-known phrase "made in USA"), unless it fulfills a modifying function in the sentence. The latter use has been invariably followed in all the media, but when the acronym acts as a noun the two forms are employed in correlation with the style of speech used in the text: in general, USA is much rnore frequently used in formal texts whereas US is the favoured variant for the conversational and informal level where it alternates with the names the States and America.

Historically, USA can be considered as an ellipsis of a third variant, US of $A$, which is the original form and was the most commonly used throughout the 19th century, as I have already pointed out. Its use today is very sporadic and occurs mostly in sentences with a humorous turn, such as "in the good old US of A" ( $c f$. also Ross 1977).

In the Romance languages ellipsis is particularly favoured in a series of acronyms which stand for names of communist parties. Following a rule by the III International (Komintern) the official name of political parties had to be PC plus the initial of the corresponding nation: e.g. PCE (Partido Comunista de España), PCF (Parti communiste français), PCP (Partido Comunista Portugués), etc. Now, as frequently happens today, when reference is made in journalistic texts to communist parties politically aligned with the Russian CP, the final initial is suppressed and thus the only form used is PC, which fulfills a descriptive rather than an identifying function while still allowing for the same possibilities of co-reference. Stylistic variation is very clear in the following Portuguese example:

Octavio Rodríguez Pato [...] é membre [...] do Secretariado do Comité Central do PCP. Foi deputado á Assembleia constituyente e responsável pelo grupo parlamentar do $\mathrm{PC}^{9}$.

In the same way, PS is the customary form to refer to the French Parti socialiste français (PSF). In Spain, however, PS is much less frequently employed as a variant of the socialist party in power (PSOE) for the socialist label has never been exclusive to it, even in recent times in which the former socialist groups have been integrated or have disappeared. The situation in Portugal is very different: here, the adjective Portugués is not included in the official name of the main socialist party (PS), nor has it ever been found in usage, despite the fact that there is more than one party with the same political colour and unlike the older name ASP (Ação Socialista Portuguesa) where P (for Portuguese) did appear. In part this is due probably to the homophony of *PSP and PCP, its traditional political rival on the left, to which one would have to add the homonymy with PSP (Policía da Segurança Pública), an institution with not precisely appealing associations in the context of Salazar's dictatorial regime.

Double acronyms by ellipsis are originated generally in the written media and, as has been noted, they correspond exactly to the ellipsis produced in their full forms. There are cases, however, in which the acronym has an autonomous oral development. A good example in English is the conversational use of "Y" (e.g. "I'm going to the Y", "I'm staying at the Y") as an abbreviation of YMCA (Young Men's Christian Association) ${ }^{10}$, and also elliptical is the form /wai-emz/ (cf. Hansen 1959: 386 whyms [sic]) with which its members have been humorously referred to. Oral usage has also produced the shortening of $\mathrm{BBC}$ to $\mathrm{Beeb}$, as the British television company is popularly known; hence its frequent use in popular newspapers like the sensationalist The Sun. The same phenomenon can be presumed to be behind an older example taken from the American military slang of the 
Second World War: CN or NC, which were two ways of clipping the acronym CNC (Chinese National Currency) ${ }^{11}$.

Closely linked with ellipsis in its most usual pattern (suppression of one element and its corresponding initial) is "extension", which forms a counterpoint to it. Thus we can interpret, for example, LORU (Ley Orgánica de Reforma Universitaria) ${ }^{12}$ as contrasted with the well-known LRU, and probably also NOAL (Movimiento de Países No Alineados) $)^{13}$ vs. NNA (países neutrales y no alineados) $)^{14}$; in the latter pair (NOAL, NNA) we could also point out a different segmentation of the underlying phrase, as was explained in the preceeding section.

This assumed extension should be understood in reference to the denomination that becomes more familiar through the media, for it is not always easy to determine exactly which is the original form. In some cases the two underlying phrases of the acronyms may have arisen almost simultaneously and independently, as if they were two different bases, a point which I will explain later. That is what may have happened for instance with the English acronyms DSOM (dynamics of soil organic matter) and DSOMS (dynamics of soil organic matter system) (cf. Conseil 1983).

A peculiar example of double acronym by extension or lengthening is English yuppies (young urban professionals) and yumpies (young urban mobile professionals). The term yuppies has been rapidly diffused in a great number of languages to designate a new social category: the young and thriving urban professionals; the initials of the acronym have received the hypocoristic suffix $-y,-i e$ and there is a strong association with yippies and hippies. Some would claim that the original and true underlying phrase includes the adjective upwardly instead of urban, in which case the acronym lexeme would remain unchanged. But others, in an attempt to stress the two meanings, have kept urban before mobile, which has been added instead of its synonym upwardly thus yielding a similar word, yumpies ${ }^{15}$.

A special case of lengthening, of a very different nature from the others and already referred to above, are the expansions or extensions of acronyms, by which a well-known acronym becomes the segment of a more complex denomination. At times, as in the examples quoted (COPYME, CEPYME), the shape of the base acronym remains intact in the extended form. In other cases the graphemes are abbreviated but there is always a conscious attempt to identify the integrated initials, which accounts for the systematic nature of the reduction. A recurrent pattern is the integration in the acronym of a plural phrase established in the written language as a reduplicated abbreviation (and thus technically an "abbreviation") by means of single initials. For example CC.OO. (Comisiones Obreras) systematically becomes CO when it appears in the following acronyms: CECO (Coordinadora de Euskadi de Comisiones Obreras), COE (Comisiones Obreras de Empresa), COJ (Comisiones Obreras Juveniles), CONE (Comisiones Obreras Nacionales de Euskadi). Likewise, CC.AA. (Comunidades Autónomas) is shortened to CA in LOFCA (Ley Orgánica de Financiación de las Comunidades Autónomas).

When both an abbreviation and an acronym are used to represent the same denomination, it is the acronym which is integrated: in ISFAS (Instituto Social de las Fuerzas Armadas) FAS and not *FF. AA. (or FA) are the initials selected.

\section{DOUBLE UNDERLYING PHRASE}

The types so far examined can be considered, strictly speaking, as modifications made upon one single original form and some of the acronyms, especially the ones described in the section on ellipsis, could be analysed within the frame of textual synonymy ("co-reference"). More synonymic in nature, however, are the acronyms derived from different underlying syntagms, as we shall see shortly. 
The underlying phrases are completely different, for example, in Great Britain (GB) / United Kingdom (UK), which are equivalent names having a very uneven distribution. Whereas both full forms are found in the written and spoken language, UK is practically the only acronym used. The reason for this is not accidental since preference has been given to the apparently more Anglo-Saxon term, and the most technical and comprehensive, inasmuch as the referent also encompasses Northern Ireland ${ }^{16} ; \mathrm{GB}$, on the other hand, sounds pompous. As far as I know, GB is only found in geographic texts and on car license plates; the latter usage is probably due to the fact that the initials are a sequence easy for Continentals to memorize, in particular those of Latin origin.

A curious example of synonyms in common nouns are the acronyms GOMER (get out of my emergency room) and LOL in NAD (little old lady in no apparent distress). They belong to American medical slang and they are used to make ironic reference to certain patients who enjoy hospital comfort and yet have no critical or immediate physical problems ( $c f$. Green 1984).

Apart from these two cases, the remaining types of synonymous acronyms attested share at least one lexeme in the underlying syntagm; normally only one word differs. Thus, in English, to refer to a job dismissal RIF (reduction in force) and RIP (reduction in personnel) are used, and in the field of economics small and medium sized enterprises (SME) are also known as small and medium undertakings (SMU) and small and mediumsized business (SMB); in French for the gross vehicle weight permitted (GVW) there are two equivalent acronyms taken from two different phrases, PMA (poids maximal autorisé en charge) and PTC (poids total en charge), and the same occurs with the gross national product (GNP): PNB (produit national brut), PSB (produit social brut); in Spanish the intensive care unit (ICU) is knowns as UCI (unidad de cuidados intensivos) and UVI (unidad de vigilancia intensiva).

The term which differs may indicate a different register (or style) or may be found in a different field of usage (or technolect) and the resulting acronym may then show a different social distribution, but there is not always an exact correlation between the two. In terms of register, in the English series SMU, SME, SMB mentioned above, Business is the most colloquial term as contrasted with the more formal undertakings and enterprise, although none of these acronyms is well-known and they rarely occur in journalistic texts. Likewise, in terms of field of usage, the forementioned RIF/RIP provides us with a good example. The former originated in the distinguished circles of Washington administration (Baum 1955: 109), but today it forms part of military (De Sola 1987) as well as economic jargon (Green 1984); RIP does not seem to enjoy the same usage and is attested only by De Sola (1987).

A more clear differentiation is shown by the already quoted Spanish UVI/UCI whose conditions of use today are somewhat complex. The former is the original form and the most widespread even in speech, to such an extent that it has given rise to metaphorical uses (e.g. of a firm or of a bank we say that han entrado en la UVI "have gone into the ICU" when they are in a precarious financial position and therefore require urgent support). Among hospital staff (doctors and nurses) UVI has existed side by side with UCI which has been gaining ground lately and is on the way to being generalized in that circle from where it has sprung into the media (and among them magazines of wide and popular readership like Interviu and Hola) which use both terms, at times even within the same issue ${ }^{17}$.

The growing use of UCI has to do with the more positive connotations of the colloquial term cuidados "care", which reflects a more complex reality since it tries to stress the greater attention and better treatment which intensive medical service offers the sick. The word vigilancia "vigilance", on the contrary, proves more formal, neutral and distant. 
In speech the use of the acronym UVI alternates with the use of the phrase cuidados intensivos, which is reduced to intensivos "intensive" among nurses. (Specialists in this field receive the name of intensivistas).

A similar though simpler differentiation is shown by the acronyms MCE/CEE. Although the two have a typically journalistic use, the first never occurs in speech, even in broadcasting, despite the fact that Mercado Común "Common Market" is used frequently in conversation.

The existence of two or more equivalent sources does not necessarily entail the coining of synonymous acronyms; as we have just noticed, in Spanish there is only one acronym, although occasionally used, to refer to the Common Market, and this is something that does not occur in French or English. It is not surprising, then, to find this name cited in English as the Common Market (EEC) ${ }^{18}$.

Finally, it should be stressed that the variation of the underlying phrase takes place at a lexical rather than at a syntactic level. In effect, as already said, the differentiation of one single lexeme in the underlying syntagm ( $c f$. English force/personnel, Sp. cuidados / vigilancia, Fr. maximal / total) usually has an effect on the process of acronymy; the same has occurred with the pair developpés/avancés in the French phrase pays les moins developpés (L.L.D.C.)/pays les moins advancés (PMA), even though the former acronym is based on an English source (least developed countries). If we now turn to syntactic variation such as pays en developpement, pays en voie de développmement and pays moins développés, we notice that they are all registered as equivalent sources and have only given rise to one acronym, PVD ( $c f$. Conseil). The multiplication of acronyms would have gone against the characteristically "synthemic" condition of the acronym ( $c f$. Calvet 1980: 35-36; Rodríguez González 1980: 15-17; 1984a). Nevetherless, this does not mean that sometimes an analogous English example would not show the most frequent phrase - e.g. developing countries - is not exactly the acronymized phrase - less developed countries (LDC) -.

On the basis of the synthemic nature of the acronym, the lexemes which form the underlying syntagm have fixed order, but this rule may be broken at times in common noun phrases prone to variation in the order of their constituents, one of which is usually an adjective. In the Romance languages, one typical variation is found in the order of the adjectives, as witness PIB (producto interior bruto), which is the form used in Spain, and PBI (producto bruto interior), as used in Argentina and other parts of South America.

Another type of phrase with a high degree of variation, in the Romance as well as in the Germanic languages, is formed by two noun elements and one modifier, as is shown in English by "system of generalized preferences" (SGP)/ "generalized system of preferences" (GSP). The Multilingual Glossary of Abbreviations (Conseil 1983: 419) registers variation of this phrase also in French (SPG, système de préférences généralisées /SGP, système généralisé de préférences) and Dutch (SAP, stelsel/systeem van algemene preferenties/APS, algemeen preferentiestelsel/systeem).

- As with "double graphemic representation", double sources of acronyms can be considered on a diachronic level, in that denominations sometimes undergo changes for various reasons. As is usually the case, the change of names is prompted by euphemistic demands, that is, by the need to avoid negative associations or to diminish them when they occur. In the jargon of Spanish Universities, the name which was used to refer to the non-teaching staff, PND (personal no docente), was recently changed to the more technical and dignified PAS (Personal de Administración y Servicios).

This fact is especially evident in the sexual and political fields. Thus, in English, venereal diseases are colloquially known by the initials VD. In spite of the euphemistic 
character of this term (from venereal, adjectival form of Venus - Venus' disease), which is reinforced by the abbreviation itself, and the greater sexual freedom of modern society, it is still felt to be taboo on account of its reference to diseases like gonorrhea and syphilis traditionally associated with $\sin$. This explains the growing use in the media of the periphrasis "sexually transmitted disease" and its corresponding initials STD, which constitutes a more technical and comprehensive term in agreement with the aseptic nature of present-day scientific terminology. (One turns, for example, to the latter and not to the former to talk of the new disease known as AIDS) ${ }^{19}$.

As this example well shows, euphemistic substitutions do not necessarily entail the immediate removal of the stigmatized term; on the contrary, they may both coexist for some time, although frequently differing in connotative meaning. With names of political institutions, however, the co-ocurrence of forms is more difficult to conceive, for when the substitution is made it is with the aim of producing immediate effects. When an acronym has developed markedly negative associations, the state institutions take it upon themselves to find a new symbol, which is soon put into circulation, as if by decree, and becomes accepted despite the criticism that might be leveled against it at first. In Chile, for example, the much criticised DINA (Dirección de Inteligencia Nacional Anticomunista) under the Pinochet regime was replaced by the CNI (Central Nacional de Inteligencia) whose specific structure ("initialism" instead of "acronym" stricto sensu) might not have been accidental.

On other occasions instead of the substitution of the whole acronym we find the partial modification of its form - together with the changes in the underlying source that would go with it - by means of substitution, omission or addition of an initial grapheme. These changes are made to avoid awkward homonymic conflicts, or, at least, to make the meaning of some connotations more positive, and in so doing they are helped by the high symbolic value of initials.

- Illustrative cases of substitution of one grapheme in the Spanish political scene are the changes of MULA to MULC and UL to PL. As for the former, MULA (Mando Unico para la Lucha Antiterrorista) was the original form, but the association with the animal of the same name ("mule") and the brute force that is attributed to it made the acronym inappropriate to refer to a police group, for which reason a few weeks later it was replaced by MULC (Mando Unico para la Lucha Contraterrorista). The change was made then simply by substituting one prefix contra for another (anti), even if the former is less frequent and the resulting acronymic lexeme difficult to pronounce and goes against the phonotactic rules of Spanish ( $c f$. Rodríguez González 1983: 212).

UL (Unión Liberal) was the name with which the liberals entered the legislative elections of 1982. At a glance the acronym did not pose problems, but time would reveal its unfortunate coinage: in the televised count that followed the election it sounded hilarious to hear the newscaster pronounce over and over again UL / u-éle/, due to its homophony with huele "it smells". It was not surprising, then, that after the elections, the party became PL (Partido Liberal).

- As an example of omission (or ellipsis) of one initial, we may mention the substitution of ACP for ACNP (Asociación Católica Nacional de Propagandistas) and that of the recent IB for the INB (Instituto Nacional de Bachillerato). The dropping of the qualifier Nacional (N), which carried a strong Francoist echo, was prompted by the new democratic winds that blew during the transitional period. One should also remember that the so-called MEC (Ministerio de Educación y Ciencia) was formerly named Ministerio de Educación Nacional. This rejection is to be contrasted with the fondness for the term that is felt at the other end of the ideological spectrum, as is shown by the new FN (Frente 
Nacional) which has taken over from the ultra-right militant groups formerly gathered around FN (Fuerza Nueva).

- The addition of one grapheme is well exemplified by the initials AD /a-dé/ (Acción Democrática). Such was the name with which the social-democratic group led by F. Fernández Ordóñez split off from the UCD party, their members being thereafter called adecos. A few weeks later, however, a P was added making PAD / pad/ (Partido de Acción Democrática) - their members being sometimes called padicos - and with this name they joined the PSOE ( $c f$. Rodríguez González 1989: 225, 236). The change of name was also a change of image. By adding the $\mathrm{P}$ of Partido they introduced a symbol strongly associated with left-wing groups (PSOE, PTE, PCE, PSA) while avoiding probable associations with the initials $\mathrm{AP}$ /a-pé/, similarly pronounced, which represented the group with the most marked right-wing leanings.

A quite different case of double acronym by addition of a grapheme is PSU/PSUC. The former is the historical and original form of the party of Catalan communists, and as such it is still used today by many of its members together with PSUC /(p)suk/, which is the generalized variant and coincides with the present anagram of the party. The sociolinguistic correlations of these two variants ( $c f$. Rodríguez González 1982: $365 \mathrm{ff}$. on this point) are not attached as strongly to values as the ones in the previous examples, which explains the survival of the two.

When there are no clear value assessments or euphemistic reasons for change, but other conditions exist that prompt an organization to change its official name, the norm is to try to keep the same initials so that the publicity value of the slogan is not lost. This is what happened when TWA (Trans World Airlines) was substituted for TWA (Transcontinental and Western Air) and CIO (Congress of Industrial Organizations) for CIO (Committee on Industrial Organization) ( $c f$. Hockett 1958: 316). In Spanish one can recall the Grupo de Acción No Violenta Anti-OTAN (GANVA), a Barcelona pacifist group born in 1978 which became Gamba (Grupo Antimilitarista de Barcelona), thus keeping the same pronunciation, despite a slight spelling change.

\section{DOUBLE CODE (TRANSLATION)}

The main source of double acronyms in the majority of languages is translation. When faced with a concept or organization of foreign origin, one normally expects a single acronym form to be adopted, either through the translation of its underlying phrase or through the direct borrowing of the alien form (e.g., LP, VHS as borrowed from English). In another article (Rodríguez González 1991) I have explained in detail, in a general way, the different cases in which language use turns to one method or another. Here I will focus my attention mainly on the linguistic conditions which account for the most recurrent vacillations.

A group of acronyms where the two tendencies lead to noticeable inconsistencies is the one which refers to the increasing number of concepts that appear in the most diverse fields of science: biology, chemistry, medicine, computer science, data processing. On the one hand, it is easy to see the convenience of using the Spanish ADN (ácido desoxirribonucleico) instead of the English DNA (desoxyribonucleic acid) or DEG (derechos especiales de giro) instead of SDR (Special Drawing Rights) within a well-established text, as Martinez de Sousa (1984: 42) argues. On the other hand, no one will deny the advantages brought to the international scientific community by adopting a common code, as some scientists and lexicographers have been claiming.

According to Martín-Municio (1986: 108), in the face of the chaos which would result from the inversion or alteration of initials belonging to the scientific field, there is 
no alternative to accepting and adopting the acronyms in their original form, which is in any case internationally established. This seems to be the way the Spanish Royal Academy of Sciences has understood the matter as it uniformly adopts the international version of terminology elaborated through acronyms for its Vocabulary. The argument and the measure gain strength from Martín-Municio's account of how some authors object to saying DNA (they write and say ADN instead) but not to saying ATP (which in Spanish should be ATF), ACTH (in Spanish it should be HACT) or VLDL (in Spanish it should be LVLD). And the thesis is further strenghened by observing the fluctuations that occur even in a newspaper as renowned and influential as El País ${ }^{20}$.

Similar positions are also taken in French. In 1962 J.C. Sournia (cit. by Poinsotte 1977: 32), in an article published in Le Concours Médical, said with regard to anglomania:

La traduction est également nécessaire pour les sigles. Alors que nos journaux parlent de l'O.M.S. et de I'O.N.U. et non pas de l'U.N.O. et du W.H.O., pourquoi avons-nous adopté sans barguigner A.C.T.H. et F.S.H.?

Now, a quarter of a century later, ACTH and FSH form part of the current medical jargon, and in view of this we have no alternative but to agree with Martin-Valiquette (1986: 33) that:

On peu évidemment traduire la FSH par hormone folliculo-stimulante, la TSH par hormone thyrotropique, la GH par hormone de croissance et ainsi de suite, mais, dans un contexte oì le sigle s'impose, il faut savoir que FSH et GH son bien ceux utilisés en français par rapport à toute tentative de francisation de ces mêmes sigles.

In spite of the logic of these countercharges, with which I agree in principle, it does not seem as if borrowing in the scientific field is always necessary or desirable, since in certain cases this would clash with rules of usage which also have their logic. OVNI and SIDA are good examples of this. To take the first of these, UFO as well as OVNI are easily pronounced "acronyms". The almost total displacement of English UFO (Unidentified Flying Object) can be explained if one takes into account the popular fascination with objetos volantes no identificados (popularly known before as "flying saucers") and the resulting familiarization with that phrase in Spanish. The mark of UFO has been left, however, on the derivatives ufólogos and ufología, which are especially suited for a scientific register and turn out to be more euphonic than the native counterpart *ovnilogía.

SIDA (síndrome de inmunodeficiencia adcquirida), in its turn, like other technical terms of foreign invention, came to the fore in its English form, AIDS (Acquired Immunodeficiency Syndrome), and was thus attested repeatedly in the media in the early stages. Soon hesitations between the English and the Spanish form appeared, before SIDA finally prevailed. On the one hand, the spread of the disease and the vast coverage it received, as if it were a plague, introduced the expression and its acronym into everyday language; on the other, the English acronym proved inappropriate since it lacked a natural syllabification and, furthermore, the sequence of its two final initials constituted a phonotactic constraint difficult to overcome (on this point, see Rodríguez González 1982).

That euphony or sonority is not always decisive is quite evident in the pair IDE / SDI, where the process seems to be reversed. IDE made an entry in the media as a translation of SDI (Strategic Defense Initiative), a technical and euphemistic name with which Reagan's programme of the militarization of space was made known. The special "acronymic" shape of IDE in Spanish made the initials easily pronounceable, far from the coldness of the "initialism" SDI. In the end, however, SDI is the form that has prevailed in the national newspapers while IDE is only found in provincial dailies ${ }^{21}$ and publications of limited readership ${ }^{22}$. This can be explained if one considers the nature of this 
acronym, a term from military jargon found almost exclusively in journalism, in particular in sections devoted to political information. Although the subject of the arms race is no doubt of general interest, it is a highly specialized topic followed in detail mostly by a minority or cultivated readership. For the average speaker the concept of SDI is better conveyed by the expression guerra de las galaxias ("Star Wars") which has become very popular and is used in the media as an explanatory paraphrase.

The last example is indicative of the decisive role which may be played by the lexical fields to which acronyms relate, regardless of the formal features that these may show. This fact is worth underlining since the lexical fields exhibit varying degrees of translatability, as a quick glance at some texts from Spanish scientific publications would show.

In the domain of computer sciences, for instance, translation is rare due to the strong mark made by English, which causes Spanish people to accept practically all acronyms in their original form. The following terms taken from a journal of electronics ${ }^{23}$ give good evidence: diseño asistido por ordenador (CAD), integración a escala elevada (LSI), circuitos integrados para aplicaciones especificas (ASIC), circuitos integrados (IC). The latter also occurs in the specialized sections of El País Semanal where we also find ordenador personal (PC) and disco compacto (or compact disc, CD), which are particularly noticeable given the simple structure of the phrases.

Of the numerous acronyms and abbreviations compiled in the Diccionario McGraw-Hill de Computación, only four have in fact been translated into Spanish, namely, control automático de frecuencia (CAF), control automático de ganancia (CAG), control automático de volumen $(\mathrm{CAV})$, circuito integrado $(\mathrm{CI})$, frecuencia intermedia (i-f). If these expressions have anything in common it is the presence of commonly used words, in contrast with the markedly technical and specialized nature of computer science terminology as a whole.

This criterion is revealing when one compares the patterns found in areas closely related to medicine. If we turn our attention to the already cited acronyms DNA (from the field of biology), we realize how technical and complex in their morphology they are, as compared to expressions like enfermedades de transmisión sexual (ETS), virus de unmunodeficiencia humana (VIH), enfermedad inflamatoria pélvica (IEIP), which belong to the field of immunology and are found in specialized journals.

Moreover, in the light of this, we can now understand the reason why some authors, according to Martín-Municio, say ADN (and ARN, we could add) in Spanish, whereas they consistently use ATP and ACTH, which are of English origin. If the former and not the latter have been turned into Spanish, although with variations, it must be on account of their greater frequency and memorability (cf. ácido vs. trifosfato or hormona; (desoxir)ribonucleico vs adenosina or adrenocorticotrópica). This would also explain why ADN (and ARN) is the form found in school handbooks whereas in University handbooks and texts written for and by scientists DNA occurs with considerable frequency. The same fact in part helps to answer the question asked by Sournia (1962), and referred to earlier, about the reason that led French medical language to adopt ACTH and FSH without hesitation, while at the same time OMS (Organisation Mondiale de la Santé) and not WHO (World Health Organization) was used.

In the process that leads to the calque or translation of a foreign acronym it is not difficult to find fluctuations at first before usage finally establishes a single form. Such fluctuations are produced by unfamiliarity with the concept or the acronym which names it, and for that reason it is not unusual to find them even within the same publication and over a very short period of time. I have already mentioned the variation of AIDS/SIDA, and elsewhere (Rodríguez González 1984b: 339) I have referred to the fluctuations of 
NATO/OTAN in the 50s. Also, at about the same time, in the newsmagazine SP we find $\mathrm{DDR}^{24}$ and $\mathrm{RDA}^{25}$ to refer to the Democratic Republic of Germany, and BIRD 26 and IBRD $^{27}$ for the International Bank for Reconstruction and Development; today the established forms are respectively RDA and BIRD, which are obtained by translation of their original acronyms.

With regard to proper names (of organizations, etc.), normally one form, generally the foreign one, is eventually discarded, although in some cases variation occurs after a long period of time, as in OTAN/NATO. Even though OTAN is by far the most usual variant, NATO is still familiar to many, which explains why both forms are found in alternation, as a stylistic device, as in the following texts:

A mí, por ejemplo, me parece una monstruosidad que entremos en la NATO y llevo mi pegatina de "No a la OTAN"28.

Pero el holandés Luns, secretario general de la NATO, estaba contento: "La cohesión de la OTAN queda reforzada", dijo en eco a las palabras de Ford: "Es una victoria de la Alianza Atlántica" 29.

If we consider that both forms are familiar to the reader, stylistic variation must be taken as a normal and permissible fact of language, all the more if the two occur at a short distance from each other; but otherwise, the variation might cause confusion and therefore should be avoided. This is precisely what happens in the Basque daily Egin (29/11/1986: 18) where, under the headline "Los soldados franceses de FINUL se van de Líbano", and after the explanatory gloss Fuerza de Interposición [sic] de las Naciones Unidas en Líbano, we find two occurrences of UNIFIL, which is the English version of the acronym.

Even if acronyms are well known, variation may not be advisable in some very special texts (microtexts) such as tables, advertisements, lexicographic entries, etc. In another article (Rodríguez González 1986: 144) I have already criticized the use of OTAN/ NATO in different entries of the same dictionary of acronyms, since in a reference work, clarity should prevail above all. Also, the alternation of EE.UU./USA, which is currently found in written (especially journalistic) texts, is striking and does not seem very justifiable in a list of films included in El País daily:

Día 1. Down by law (Bajo el peso de la ley) de Jim Jarmusch (EE.UU., 1986).

The fly (La mosca), de David Cronember (USA, 1986). Viernes y sábados, sesión de madrugada, 0,45 horas ${ }^{30}$.

A peculiar type of stylistic variation is found occasionally in reference to some political parties. As explained in Rodríguez González (1991), normal usage favours sticking to the original form, but on occasions some writers or journalists take certain liberties by using in their own language the initials of a descriptive rather than an identifying name as a co-referential term of the acronym.

A good illustration of this in English is the use of abbreviations of "classical" ideological labels ( $c f$. Rodríguez González 1988: 69) as a (textual) synonym of the official name of political parties in countries where the language spoken is of Romance origin; e.g. SP (Socialist Party) and CP (Communist Party) ${ }^{31}$, used to refer to Portuguese PS (Partido Socialista) and PCP (Partido Comunista Portugués), CD (Christian Democrats) ${ }^{32}$ instead of DCI (Democracia Cristiana Italiana). As can be noted, morphologically these variants are characterized by the inversion of the "characterizing" initials (SP, CP), appropriate to English syntax, and/or the ellipsis of the "identifying" grapheme (I = Italiano, $\mathbf{P}=$ Portugués). 
A special type of double acronym is obtained by using the two sets of initials in a juxtaposed form. This is a characteristic pattern of certain bilingual communities where, in some cases, for practical reasons the two acronymic lexemes are adopted, being separated by a dash or a bar. Thus in Switzerland, where French and German predominate, the acronyms SVD/ASD (Schwizerische Vereinigung für Documentation/Association suisse de documentation) and SDA-ATS (Schweizerische Depeschenagentur - Agence Télégraphique Suisse) are both in circulation. In Belgium, the University of Brussels is known by the French and Dutch initials V.U.B.-U.L.B. (Vrije Universiteit Brussel/Université Libre de Bruxelles). Similarly, in Spain the Universidad Pública del País Vasco is referred to in a Basque daily as EHU/UPV ${ }^{33}$.

Confusion may easily arise as soon as the two forms alternate with a single one, as occasionally happens with some acronyms. Thus for example in Spain one frequently refers to the Basque trade union ELA-STV, this form consisting of the Basque initials ELA (Eusko Langileen Aikartasuna) followed by their corresponding Spanish ones, STV (Solidaridad de Trabajadores Vascos). However, in some texts only ELA occurs, as if it were an ellipsis; this form has been found several times in the daily El País in chronicles written by news correspondents living in the Basque country.

Easier to account for is the occurrence of ELA in typically Basque nationalist newspapers like Egin and Deia where this acronym has reached a significant frequency. Although variation may be found within a single issue, sometimes the distribution of the variants has a clear correlation; a very illuminating example is one obituary notice published in Deia both in Basque and Spanish where both ELA and ELA-STV occur in correspondence with the languages used ${ }^{34}$.

As noted thus far, the most characteristic pattern of double acronym stems from both borrowing the acronymic form directly and translating its underlying source. This translation can give rise in its turn to two different phrases in the target language and thereby result in a double acronym.

The double phrase can be obtained if its foreign counterpart contains a lexeme which can be translated by way of two or more synonyms. Thus the English initials IBRD (International Bank for Reconstruction and Development), which were once used to refer to today's World Bank, have been used as a translation of BIRF (Banco Internacional de Reconstrucción y Fomento) in Latin American countries whereas in Spain BIRD has been the preferred form ( $c f$. supra); so one single word, Development, has been translated in two ways, as Desarrollo and Fomento. The same occurs with IDA (International Development Association) which has given rise to AID (Asociación Internacional de Desarrollo) and AIF. Both acronyms are listed in Martínez de Sousa's dictionary of acronyms (1984), where one can also find GATT (General Agreement on Tariffs and Trade) and two translated variants, namely: AGTC (Acuerdo General sobre Tarifas y Comercio) and AGAAC (Acuerdo General sobre Aranceles Aduaneros y Comercio); in the latter case an English word, Tariffs, has been turned in Spanish into its literal (or cognate) equivalent, Tarifas, and as a periphrastic synonym, Aranceles Aduaneros. In the face of this dilemma my feeling is that one should tend towards the most literal translation where possible, even if the phrasing is impaired, so that the differences between foreign and native acronyms are kept to the minimum. In this way I consider the Spanish FMCE (Federación Mundial Cristiana de Estudiantes) an unfortunate translation for the international organization FUACE (Fédération universelle des associations chrétiennes d'étudiants), as registered by Martínez de Sousa (1984). No doubt the translation is well done and gains in brevity, but it is not altogether acceptable for the acronym obtained is 
very different and much less euphonic. One should therefore prefer FUACE (Federación universal de asociaciones cristianas de estudiantes), which is the form found in Alvar and Miró (1983).

II The double phrasing obtained through translation may be achieved by a change in word-order of the constituents. This can come about due to error, or to little or no familiariaty with the established use of the acronym, especially in the early stages of usage. Thus in Portuguese, in addition to CAME (Conselho de Assistencia Mútua Económica) ${ }^{35}$, for which the English form COMECON is also used, I have documented CAEM (Conselho de Ayuda Económica Mútua) ${ }^{36}$. The three are attested at about the same time in one single magazine (Seara Nova), and they are also found in Spanish, as registered by Martínez de Sousa (1984), who includes yet another variant, CMEA. This form is, on the other hand, the one found in news bulletins published in English by the Soviet Foreign Affairs office (Foreign News) and the East German Foreign Affairs Bulletin, even though the general form in English as well as in Spanish and other languages is COMECON ${ }^{37}$ and the native Russian counterpart is SEW (Soviet Ekonitscheskoi Vsaimopomostschi). Incidentally, one should notice, however, that COMECON and CMEA do not differ in the syntactic order of their elements, both coming from Council for Mutual Economic Asssistance, but rather in their graphemic and phonetic representation.

Syntactic variation may result in totally unacceptable forms in certain cases. Accustomed to reading in the Spanish press the acronyms POUP (Partido Obrero Unificado Polaco) and RASD (República Arabe Saharaui Democrática), one is surprised to find in the careful and influential daily El País the initials POPU (Partido Obrero Polaco Unificado) ${ }^{38}$ and RADS (República Arabe Democrática Saharaui) ${ }^{39}$, which seem to be mere mistakes. Stranger yet is the form SDIA (síndrome de deficiencia inmunológica adquirida) as the variant of the well-known SIDA, which could be accepted as a translation if it were not for its awkward pronunciation. The change in the phrasing and the order of the underlying syntagm (deficiencia inmunológica instead of inmunodeficiencia) reveals the translator's lack of contact with Spanish reality, which perhaps is not at all surprising if we consider that the text in which it was found belongs to the Spanish version of an English magazine written in $1983^{40}$, a time when the use of SIDA had not been completely established and therefore competed with the English form AIDS ( $c f$. supra).

\section{CONCLUDING REMARKS}

Acronyms basically constitute a specialized technical lexicon, hence the need for them to be univocal and standardized, all the more so since many of them refer to concepts of international use. However, with some acronyms speakers are at times led to different variants due to the composite and complex structure of their underlying phrases as well as to the unfamiliarity which this may cause.

The condition of designation or "denomination" - rather than of "name" or apellative - on which many acronyms are based, inclines the writer or speaker to choose a single signifier. As so often happens with synonyms, acronym variants, once the double use is established, are sometimes distributed in correlation with pragmatic and sociolinguistic parametres like user (speaker or writer) and addressee, medium, style, type of journal, etc.

The most noteworthy variations in the conditions of use of acronyms should be pointed out in journalistic stylebooks (and even kept up-to-date by means of interim memoranda) as well as in dictionaries of acronyms (whether general or specialized, bilingual or multilingual) so that the writer, journalist, or the translator can find in them any help necessary to dispel doubts and avoid mistakes. 
However contradictory it may sound, these lexicographic works would have the additional effect of contributing to the standardization of acronyms, a need felt most acutely within the field of technology. In the "global village" in which we live, the scientist more than anyone else needs single signifiers for his conceptualizations, and in this context one cannot but praise all attempts to lay out rules that put an end to the multiplicity of forms. However, it must be stressed that where they exist, variants of a certain frequency should be tolerated and consequently registered, for were it not so the reader or writer would often be left helpless.

\section{Notes}

1. This acronym is out of use today as it belonged to the student slang of the 70s. In Alvar and Miro's dictionary of acronyms (1983) only DAC is documented, but DEAC is the form which seems to have been most used, to such an extent that it has been attested also in small letters ("El equívoco nació en que la negativa fue comunicada al deac de la Escuela de Formación del Profesorado de e.g. B. [...], Norte de Castilla, 19/2/1976: 3)

2. Heraldo Español, 16/7/1980: 6.

3. Diario de Terrasa, 12/12/1986: 13.

4. The use of this term expands the scope of meaning of "grafía hipercaracterizante" as used by Pratt (1973; 1980: 123) to refer to the appearance of grapheme features in a lexeme alien to the orthographic system of a given language.

5. SP, 1/1/1971: 25 (it occurs 4 times in the text); Triunfo, 24/1/1979: 18; El País, 2/11/1979: 47; also registered, in written form, on Televisión Española, February 1985.

6. In fact in some glosses one finds Productos (instead of Productos y Precios) Agrarios, although such deletion could be intentional given the length of the denomination.

7. For the typology of acronyms see Toconita (1965: 66) and Rodríguez González (1984a).

8. At least this is what one concludes after a scrutiny of the July 1987 issues.

9. Portugal Informação, Number 6, June-July (1976).

10. Cf. also in Quebec French: "son frère est resté au "Y"/wai/ pendant un mois" (cit. by Germain and Lapierre 1988: 66). Similarly, in German the equivalent acronym, CVJM, (Christlicher Verein Junger Männer) is at times reduced in speech to its first two initials.

11. J. L. Riordan, "A. V. G. Lingo", American Speech, 23, 1 (1948: 31).

12. Deia, $9 / 2 / 1984: 5$.

13. El País, 15/7/1982: 6.

14. Información (Alicante), 16/3/1984: 25 .

15. A third variant, attested in only one book, is YAP (young aspiring professionals), cf. Shapiro (1986).

16. According to Raymond Williams (Towards 2000, London, 1983: 193) the Yookay, as he ironically transcribes it, is a term from the jargon of commercial and political planning which lacks an historical or cultural origin.

17. Interviú, 28/7/1982: 49; Hola, 5/10/1985: 109.

18. Monthly Review, 26, 4 (1974: 47).

19. In regard to sex proper, one can mention the series of euphemistic designations coined by way of acronyms (or more exactly, "semiacronyms"): B-girls (bar-girls), $C$-girls (call girls), $J$-girls (joy girls), V-girls (the "Victory girls" of the Vietnam war, also interpreted as "vice girls").

20. El País, 4/5/1983: 23.

21. Cf. for example El Norte de Castilla (Valladolid), 23/1/1988: 37; La Nueva España (Oviedo), 23/1/1988: 19; Información (Alicante), 25/4/1985: 2.

22. Cf. En pie de Paz, Number O (February 1986: 6), I recently heard this form being used by former minister Fernando Morán in a television debate, $1 / 1 / 1988,10.30$ p.m.

23. Revista Española de Electrónica, October, 1987.

24. $S P, 18 / 1 / 1970: 5$.

25. $S P, 17 / 8 / 1969: 27$.

26. $S P, 15 / 10 / 1962: 47$.

27. Ibid., p. 19.

28. El Pais, 27/12/1982: 28.

29. Cambio 6 , 23/6/1975: 50

30. El País, 27/6/1987: 36 .

31. Paul M. Sweezy, "Class Struggles in Portugal", Monthly Review, 27, 5 (1975).

32. The New Statesman, 26/6/1987: 30.

33. Egin, 29-11-1986: 1, The order of the initials is reversed, UPV/EHU (Euskal Herriko Unibertsitatea), in ERETIM, Revista de la Universidad del País Vasco, 2 (1984: 1). 
34. "Angel María Sánchez López...Iberdueroko ELA Sindikal-Saileko kideek"/Tus compañeros de la Sección Sindical de ELA-STV de Iberduero", Deia, 9/2/1984: 10.

35. Antonio Cruz, "A integração económica socialista", Seara Nova, April, 1976: 21.

36. Olga Trofimova, "Paises do CAEM: a colaboração com "o Terceiro Mundo", Seara Nova, Nov. 1974, pp. 34-35.

37. However, reference to the acronym COMECON seems to be losing ground lately in various languages in favour of the shorter "initialistic" variants. According to Williams (1990: 55), the translators of $G D R$ Review (the English-language version for the monthly publication $D D R$-Revue) prefer the more neutral literal translation CMEA instead of the equivalent Comecon on the grounds that the connotations of the latter (i.e. Commie / con) are pejorative and conjure up images of Easten Europe which GDR Review wishes to dispel.

38. País Semanal, 27/5/1979: 23.

39. El Pais, 1/10/1976: 7.

4.0. La pura verdad, Sept. 1983: 7 (“"SDIA": Nueva epidemia mortal").

\section{REFERENCES}

ALVAR, M. and A. MIRÓ (1983): Diccionario de siglas y abreviaturas, Madrid, Alhambra.

BAUM, S. V. (1955): "From "Awol" to "Veep": the Growth and Specialization of the Acronym", American Speech, 30, pp. 103-110.

CALVET, L. J. (1980): Les sigles, Paris, Presses Universitaires de France.

Conseil des Communautés européennes (1983): Glossaire d'abréviations multilingue, Luxemburg, Office des publications officielles.

DE SOLA, Ralph (1987): Abbreviations Dictionary, 7rd ed. New York, Elsevier.

GERMAIN, C. and A. LAPIERRE (1988): "Le sigle: Définition, caractéristiques et emploi", Cahiers de lexicologie, 2, 53, pp. 55-74.

GREEN, Jonathan (1984): Newspeak: A Dictionary of Jargon, London, Routledge \& Kegan Paul.

HANSEN, Klaus (1959/1960): "Das Spiel mit der Abkürzung im Englishen", WZUB Berlin, Ges. — Sprachw, 9, 4, pp. 379-389.

HOCKETT, Charles F. (1958): A Course in Modern Linguistics, 3rd reprint, New York, Macmillan.

MARTÍN-MUNICIO, Angel (1986): "Lexicografía de la ciencia y de la técnica", Telos (Cuadernos de comunicación, tecnología y sociedad), 5, pp. 105-112.

MARTIN-VALIQUETTE, Louise (1986): "Les traquenards de la traduction médicale... ou l'interaction textetraducteur-dictionnaire", Meta, 31, pp. 31-33.

MARTÍNEZ DE SOUSA, José (1984): Diccionario internacional de siglas y acrónimos, Madrid, Pirámide.

MÜLLER-SCHOTTE, Hans (1968): "Zur Theorie und Praxis der englischen Abkürzungen", Lebende Sprachen, 8, 4-5, pp. 105-112.

POINSOTTE, Jean-Pierre (1977): De l'usage des sigles en medicine: étude critique et lexique pratique, Unpublished doctoral dissertation, Université de Nancy.

PRATT, Chris (1972-73): "El lenguaje en los medios de comunicación de masas: algunos aspectos", Filología Moderna, 46-47, pp. 63-87.

PRATT, Chris (1980): El anglicismo en el español contemporáneo, Madrid, Gredos.

RODRÍGUEZ GONZÁLEZ, Félix (1980): Estudio de las siglas en español actual, Unpublished doctoral dissertation, University of Alberta (Canada).

RODRÍGUEZ GONZÁLEZ, Félix (1982): "Variaciones fonotácticas en siglas", Revista Española de Lingüística, 13, 2, pp. 357-374.

RODRÍGUEZ GONZÁLEZ, Félix (1983): "On the Coining of Acronyms by Homonymy", Anglo-American Studies, 3, 2, pp. 209-22I.

RODRÍGUEZ GONZÁLEZ, Félix (1984a): "Taxonomía de la siglación", Proceedings of the 7th World Congress of Applied Linguistics (abstract), J. Den Haese and J. Nivette (Eds.), Brussels, ITO/VUB, vol. 3, p. 1221.

RODRÍGUEZ GONZÁLEZ, Félix (1984b): "El género de las siglas", Revista Española de Lingüistica 14, 2 , pp. 311-366.

RODRÍGUEZ GONZÁLEZ, Félix (1986): "Apuntes lexicográficos. A propósito de un diccionario general de siglas", Revista Española de Lingüistica Aplicada, 2, pp. 127-149.

RODRÍGUEZ GONZÁLEZ, Félix (1988): "The Proliferation and Use of Acronym Derivatives: Conditioning Factors", Cahiers de Lexicologie, 52, 1, pp. 65-82.

RODRÍGUEZ GONZÁLEZ, Félix (1989): "La derivación de las siglas", Boletín de la Real Academia Española, 69, 247, pp. 211-255.

RODRÍGUEZ GONZÁLEZ, Félix (1991): "Translation and Borrowing of Acronyms: Main Trends", International Review of Applied Linguistics, 29, 2, pp. 179-188. 
ROSS, Frances D. (1977): "US and its congeners", American Speech, 52, 1-2, p. 121.

SHAPIRO, F. R. (1986): "Yuppies, Yumpies, Yaps, and Computer-assisted lexicology", American Speech, 61, 2, pp. 139-146.

SOURNIA, Jean-Claude (1962): "Pourquoi parler français?", Le Concours Médical, 84, 4, p. 556.

TOCONITA, Michael J. (1965): "Abbreviations, Words Formed by Literation, and Acronymms in Three French Dictionaries", Linguistics, 15, pp. 66-77.

WILLIAMS, Jennifer (1990): "The Translation of Culture-Specific Terms", Lebende Sprachen, 2, 55-58. 